\title{
Abandoned Wells Create Liability FOR FUTURE SUBSURFACE RESOURCE EXPLOITATION
}

\author{
THERESA L. WATSON*
}

\begin{abstract}
Due to inadequate management of the liability associated with abandoned wells, wellbores will continue to pose a threat to resource development in Alberta. To mitigate this issue, a new development should be burdened with the costs of mitigating the risks of that development. Economic decisions made at the time the risk is to be imposed, in the present, will be more reasoned. Companies that follow the regulations should be able to reasonably expect that compliance with the rules will alleviate liabilities in the future. The regulated industry should be able to trust the expertise of a regulator to ensure the protection of the environment, public safety, and the subsurface resource.
\end{abstract}

\section{TABLE OF CONTENTS}

I. INTRODUCTION . . . . . . . . . . . . . . . . . . . . . . . . . 1001

II. Well CONSTRUCTION AND ABANDONMENT $\ldots \ldots \ldots \ldots \ldots \ldots \ldots . \ldots . \ldots 1003$

III. SubSURfACE RESOURCES . . . . . . . . . . . . . . . . . . . . . . 1005

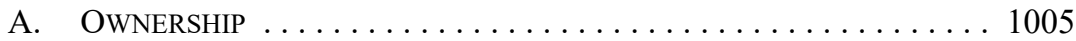

B. What is a SubSuRface ReSOURCE? . . . . . . . . . . . . . 1005

IV. HistoriC AND ONGOING SUBSURFACE CONFLICTS

ASSOCIATED WITH WELLbORES . . . . . . . . . . . . . . . . . . . . . 1007

A. Gas Over Bitumen . . . . . . . . . . . . . . . . . 1007

B. Potash Mining (SaskatcheWAN) . . . . . . . . . . . . . . . . . 1009

C. UnCONVENTIONAL OIL AND GAS . . . . . . . . . . . . . . . . . . . . . 1009

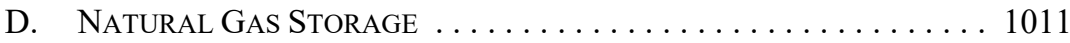

E. CARbon Dioxide Sequestration . . . . . . . . . . . . . . . . 1012

F. STACKED RESERVOIRS . . . . . . . . . . . . . . . . . . . 1012

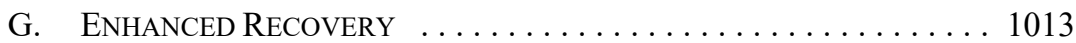

V. LEgISLATIVE AND REgULATORY BARRIERS . . . . . . . . . . . . 1014

A. OngOING LiABILITY $\ldots \ldots \ldots \ldots \ldots \ldots \ldots \ldots \ldots \ldots \ldots$

B. WELLBORE ABANDONMENT AND

CONSTRUCTION REGULATION . . . . . . . . . . . . . . . . . 1017

C. Well LiCENCING REQUiREMENTS FOR ABANDONED WELLS . . . . 1018

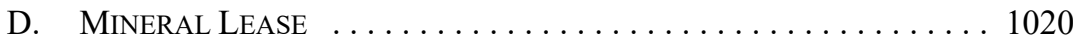

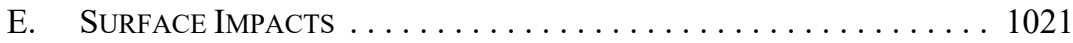

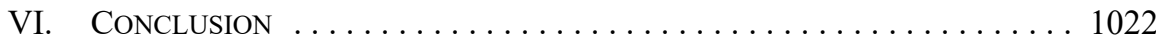

\section{INTRODUCTION}

The Earth holds valuable resources such as oil, gas, bitumen, and water that are removed from the rock pore space; the pore space itself, which is used to store fluids for future use or dispose of unwanted pollutants; rock mined for the recovery of minerals; and heat in the form geothermal energy. The future development of these resources is at risk of being sterilized due to wellbores that penetrate the strata of the Earth. 
Abandoned wells pose an increased level of threat to subsurface development because they are no longer actively monitored by a licensee or the government:

Indeed, in recent years, oil and gas operators have mistakenly fractured into old, plugged wells, causing underground pollution. Abandoned wells can also impede other important non-mineral uses of the subsurface, including the storage of natural gas, carbon dioxide, and development of geothermal resources, although they can also support certain of these uses. ${ }^{1}$

In Alberta, abandoned wells pose a threat to resource depletion since the wells were constructed and abandoned under older regulatory requirements that did not take into consideration the future use of the subsurface. For instance, there have been environmental impacts associated with hydraulic fracturing into offset neighbouring wells ${ }^{2}$ and uncontrolled bitumen releases to surface via old abandoned wells. ${ }^{3}$ The Alberta Energy Regulator (AER) has recently set out requirements that offset wells must be considered prior to fracturing ${ }^{4}$ and have imposed areas within the oil sands where steaming is not allowed due to pre-existing wellbores. ${ }^{5}$

The magnitude of the problem is daunting. There are hundreds of thousands of preexisting wellbores in Alberta and more drilled every year. These wellbores will continue to pose a threat to resource development in the future. This risk is recognized in the Oil and Gas Conservation Act, which states: "Abandonment of a well or facility does not relieve the licensee, approval holder or working interest participant from responsibility for the control or further abandonment of the well or facility or from the responsibility for the costs of doing that work." However, the current management of the liability associated with abandoned wells is inadequate to protect future resource development.

In considering how to deal with the issue of abandoned wells, policy-makers are confronted with the following questions:

- Should the licensee of a wellbore, having been abandoned decades prior to a new development, be required to abandon a well to withstand some future technology that was not contemplated at the time of abandonment?

- $\quad$ Should the licensee be required to re-enter and re-abandon a wellbore to allow for safe exploitation in the future, or should the company that will be conducting the new operations be expected to pay?

Hannah J Wiseman, "Coordinating the Oil and Gas Commons" [2014] 6 BYUL Rev 1543 at 1573 [footnotes omitted].

2 Thomas Kim, "Overview of Interwellbore Communication Incidents: An ERCB Perspective" (Address delivered at the Canadian Society of Unconventional Resources 14th Annual Conference, Calgary, 3-4 October 2012) [unpublished].

3 Canadian Natural Resources Limited, "Primrose Flow To Surface Causation Report" (Calgary: AER, 2014) at 12-2, online: <aer.ca/documents/reports/CNRL-CausationReport-20140627.pdf>.

4 Alberta Energy Regulator, “Directive 083: Hydraulic Fracturing - Subsurface Integrity,” online: < aer.ca/ documents/directives/Directive083.pdf> [D083].

Alberta Energy Regulator, "Draft Directive 023: Oil Sands Project Applications," online: $<$ aer.ca/docu ments/directives/DraftDirective023_20130528.pdf> [Draft-D023].

6 RSA 2000, c O-6, s 29 [OGCA]. 
- What is the role of the Crown to ensure that resources continue to be exploited, for the financial benefit of its citizens, in a way that ensures environmental protection and public safety?

This article first explains how wellbores are constructed and abandoned. The various subsurface resources and the ownership of these resources are then described. It then looks at historic examples of subsurface conflicts associated with wellbores and competing use of the subsurface for resource exploitation. The legislative and regulatory framework is explored to determine how wellbore liability is managed and the problems associated with the current law. Finally, in conclusion, the article sets out what should be considered in developing new policy to manage the ongoing liability of abandoned wells.

\section{Well Construction AND Abandonment}

There are approximately 560,000 licenced subsurface wells of all types, excluding most wells shallower than 150 metres (generally water and geothermal wells) in Alberta. ${ }^{7}$ Although wells have been drilled in the province since the late $1800 \mathrm{~s}$, most wells have been drilled since the $1950 \mathrm{~s}$ after the Leduc discovery in $1947 .{ }^{8}$ Based on AER data, it is estimated that there are currently over 177,000 abandoned wells in the province of Alberta. ${ }^{9}$ Most of these wells penetrate previously exploited oil, gas, and bitumen reservoirs. Generally, with the current technology, these reservoirs still contain 60 to 80 percent of original oil in place. ${ }^{10}$ It is expected that as technologies advance, further exploitation of these reservoirs will be possible, just as technology advances in horizontal drilling, multi-stage fracturing, and steamassisted gravity drainage have made previously uneconomic resources attractive. ${ }^{11}$

In Alberta, the status "abandoned" means that the well has been properly plugged downhole at any previously completed interval, any porous zone has been isolated, all nonsaline water zones have been protected, and the casing has been cut and capped below surface. ${ }^{12}$ Although these wells generally have been abandoned in accordance with the regulatory requirements at the time of abandonment, they are permanently installed in the subsurface and hence create implications for any nearby subsurface development in the future. In addition, the wells that are currently producing, inactive, or yet to be drilled will also remain in the subsurface forever.

The AER regulates the construction of wells in Alberta. Regulations have been in place since the 1940s and have been evolving as the risks associated with wells have been identified, such as resource protection, concern over public safety, and the environment.

Alberta Energy Regulator, "List Of Wells In Alberta," online: <aer.ca/documents/sts/ST37.pdf>. Gordon Jaremko, Steward: 75 Years of Alberta Energy Regulation (Calgary: Energy Resources Conservation Board, 2013) at 13, online: <aer.ca/documents/about-us/Steward Ebook.pdf>.

9 Data retrieved from Geovista 5.1 supplied by Divestco Inc. derived from the AER data [Geovista].

10 Alberta Energy Regulator, "Alberta's Energy Reserves and Supply/Demand Outlook: Executive Summary" (Calgary: AER, 2017), online: <aer.ca/documents/sts/ST98/ST98-2017 Executive Summary.pdf $>$ ["Alberta's Energy Reserves"]; Roberto F Aguilera et al, "Depletion and the Future Availability of Petroleum Resources" (2009) 30:1 Energy J 141.

11 Alastair R Lucas, Theresa Watson \& Eric Kimmel, "Regulating Multistage Hydraulic Fracturing: Challenges in a Mature Oil and Gas Jurisdiction" in Donald N Zillman et al, eds, The Law of Energy Underground: Understanding New Developments in Subsurface Production, Transmission, and Storage (Oxford: Oxford University Press, 2014) 127 at 131.

12 Alberta Energy Regulator, "Directive 020: Well Abandonment," online: < aer.ca/documents/directives/ Directive020.pdf $>$ [D020]. 
Wells are constructed by drilling a hole in the earth using a rotating bit and utilizing a viscous fluid (mud) for cuttings removal, hydrostatic control, and cooling. After the hole is drilled, steel casing is installed and cemented into place. The requirements for the casing and cementing of the well changed significantly over the history of the industry in Alberta. Over time, cementing requirements have moved from just protecting the productive zone in the wellbore to protecting potential productive porous zones penetrated by the wellbore, protecting non-saline groundwater, and finally now to industry practice of fully cementing wellbores. $^{13}$

In Alberta, a licensee must abandon a well if the licensee no longer has the mineral rights associated with it. ${ }^{14}$ The regulator may require abandonment for other reasons associated with safety, environment, or financial liability. ${ }^{15}$ However there are no prescribed timelines associated with when a well must be abandoned. That being said, eventually over time, all wells will be abandoned.

Abandoned wellbores, where the mineral lease has expired and reverted back to the Crown, are owned by the Crown. ${ }^{16}$ However, the OGCA indicates that the licensee remains as the licensee in perpetuity, and "[a]bandonment of a well or facility does not relieve the licensee, approval holder or working interest participant from responsibility for the control or further abandonment of the well or facility or from the responsibility for the costs of doing that work." ${ }^{17}$ The continued liability may create a disincentive to abandonment since access to abandoned wells is difficult due to surface development near abandoned wells, or increased cost to drill through the many plugs installed in the well during downhole abandonment.

The lack of regulatory requirements for timely abandonment of wells has created a situation in Alberta where thousands of wells are inactive and uneconomic to produce, but remain on the landscape. A combination of no requirement for timeliness of abandonment, the high cost of abandonment, loss of mineral rights after abandonment where a well holds the lease, and the threat of indefinite liability, regardless of whether a well is abandoned or not, creates a situation where companies elect to leave wells inactive for economic reasons.

Wellbore construction and abandonment requirements have been evolving as knowledge about potential risks associated with wellbores has been acquired. Original requirements were simply to abandon the producing zone with some form of permanent plug. Over time, the risk to hydrocarbon resources was recognized and those conventional resources were

13 The first casing requirement appeared in 1963 with the first cement requirements following in 1966. The cementing requirements have been updated six times with the current AER Directive 009 dated 1990: Alberta Energy Regulator, "Directive 009: Casing Cementing Minimum Requirements," online: $<$ aer.ca/documents/directives/Directive009.pdf $>$ [D009]. A complete historical list of the regulatory requirements can be found in Theresa $\mathrm{L}$ Watson, "Investigation of Wellbore Leakage for $\mathrm{CO}_{2}$ Storage" (21 July 2005) [unpublished]. The report was summarized in Theresa L Watson \& Stefan Bachu, "Evaluation of the Potential for Gas and $\mathrm{CO}_{2}$ Leakage along Wellbores" (2009) 24:1 SPE Drilling \& Completion 115.

14 Oil and Gas Conservation Rules, Alta Reg 151/1971, s 3.012(a) [OGCR].

Ibid, s 3.012(b)-(h); Alberta Energy Regulator, "Directive 006: Licensee Liability Rating (LLR) Program and Licence Transfer Process," online: <aer.ca/documents/directives/Directive006.pdf> [D006].

16 Mines and Minerals Act, RSA 2000, c M-17, s 32(1) [MMA]. Supra note 6, s 29. 
protected. Later, risks to non-saline groundwater were identified and regulations were incorporated to address these risks. ${ }^{18}$

\section{SUBSURFACE RESOURCES}

This section is intended to provide understanding of the resources in the subsurface and how wellbores are constructed and abandoned. Having this understanding will assist the reader in appreciating the current and historic conflicts described in the following section as well as form the basis to understanding the potential future conflicts.

\section{A. OWNERSHIP}

In Canada, subsurface resources are owned by freeholders or the Crown. Generally, as you move from east to west across the country, the split between these owners increases in favour of the Crown. For instance in Alberta, the provincial Crown owns 81 percent of the mineral resources with the other 19 percent owned by the federal Crown and various freehold owners, such as railroad companies that were granted lands in exchange for building the railroad, or individuals who homesteaded prior to $1887 .{ }^{19}$ In contrast, southwest Manitoba has 80 percent freehold mineral ownership because this fertile area was homesteaded prior to $1887 .^{20}$

\section{B. What is a Subsurface Resource?}

For the purposes of this discussion, "subsurface resource" means any fluid or gas that is removed from the pore space, the pore space itself, solids that are removed from the subsurface as minerals, or the heat provided by the Earth.

\section{FLUID AND GAS}

Water, oil, bitumen, and natural gas are the most common fluids and gases extracted from the subsurface. Oil, gas, and bitumen production is closely regulated by the Provinces. In Alberta, the AER is responsible for "the efficient, safe, orderly and environmentally responsible development" of these resources. ${ }^{21}$ The AER estimates that with current technologies, significant resources will remain in place; for instance, the current recovery estimates for oil are only 23 percent. $^{22}$

Watson \& Bachu, supra note 13.

Alberta Energy, "Petroleum and Natural Gas Tenure in Alberta" (Edmonton: Government of Alberta, 2016), online: <open.alberta.ca/dataset/6ba11381-43d7-4d64-a0e4-e594d9cb8b10/resource/8144bb4993d7-4428-84e2-95dfb6d8898b/download/tenure-brochure-online-version-february-15-2017.pdf $>$. Freeholders Owners Association, "About Freehold Mineral Rights," online: <fhoa.ca/member-page/ resources/about-freehold-mineral-rights/>.

Responsible Energy Development Act, SA 2012, c R-17.3, s 2(1) [REDA].

"Alberta's Energy Reserves," supra note 10, Table 1. 
Other fluid resources found in the subsurface include non-saline water ${ }^{23}$ or various useful brines such as calcium chloride. In Alberta, potable groundwater ${ }^{24}$ is generally found in the shallow subsurface at depths less than 150 metres below ground level. ${ }^{25}$ The AER heavily regulates oil and gas development to protect non-saline water from potential adverse impacts associated with oil and gas wells. For instance, regulations pertaining to the installation and cementing of surface casing, ${ }^{26}$ production casing cementing, ${ }^{27}$ and remedial cementing required at the time of abandonment ${ }^{28}$ all refer to the protection of non-saline water.

\section{2. $\quad$ SOLIDS}

Solids removed from the subsurface include coal, potash, and metals (such as gold, silver, iron, nickel, uranium, aluminium). Generally these resources are extracted through mining techniques that include underground or surface mining, solution mining, or newer technologies such as in situ coal gasification.

\section{PORE SPACE}

The pore space serves as an important storage and disposal resource. Historically, many substances have been disposed of in the subsurface due to the safe, permanent nature of disposal in subsurface reservoirs. In Alberta, hydrogen sulphide $\left(\mathrm{H}_{2} \mathrm{~S}\right)$ has been deep-welldisposed since 1989 when low sulphur prices changed $\mathrm{H}_{2} \mathrm{~S}$ from a resource to a waste byproduct of oil and gas production. ${ }^{29}$ Other waste products, including hydraulic fracturing flow back fluids, produced water, radioactive materials, and other industrial wastes have also been disposed of in the deep subsurface.

Within the last 20 years, concerns with carbon dioxide $\left(\mathrm{CO}_{2}\right)$ emission impacts on the environment have focused research on the potential to dispose of $\mathrm{CO}_{2}$ in the subsurface. ${ }^{30} \mathrm{In}$ 2010, the Alberta government amended the MMA to declare that the pore space below all of the land in Alberta belongs to the Crown (except for those lands owned by the Federal Government). ${ }^{31}$ This enactment effectively removes the rights of freehold mineral owners to use the pore space within the strata where they own the minerals. The right to pore space for the disposal of $\mathrm{CO}_{2}$ or the storage of other valuable resources, such as natural gas, is now solely at the discretion of the provincial government and, as such, a resource to be protected for future generations. solids (TDS).

Guidelines for Canadian Drinking Water Quality, Table 2, suggests that total dissolved solids be less than $500 \mathrm{mg} / \mathrm{l}$ based on aesthetic objectives, online: $<$ canada.ca/content $/ \mathrm{dam} / \mathrm{hc}$-sc/migration/hc-sc/ewhsemt/alt formats/pdf/pubs/water-eau/sum guide-res recom/sum guide-res_recom-eng.pdf $\$$.

25 Alberta Environment, "Alberta Water Wells," online: < groundwater.alberta.ca/ waterwells/d/>.

26 Alberta Energy Regulator, "Directive 008: Surface Casing Depth Requirements," online: <aer.ca/ documents/directives/Directive008.pdf>.

D009, supra note 13 .

D020, supra note 12.

HL Longworth, GC Dunn, \& M Semchuck, "Underground Disposal of Acid Gas in Alberta, Canada: Regulatory Concerns and Case Histories" (Paper delivered at the SPE Gas Technology Symposium, Calgary, 28 April - 1 May 1996) [unpublished].

International Energy Agency, "20 Years of Carbon Capture and Storage: Accelerating Future Deployment" (Paris: IEA, 2016), online: <webstore.iea.org/20-years-of-carbon-capture-and-storage> . MMA, supra note $16, \mathrm{~s} 2$. 


\section{HEAT}

Governments and investors are interested in thermal energy development such as a carbon-free energy source and believe that existing wellbores could be repurposed for geothermal energy production. ${ }^{32}$ Shallow geothermal wells can be used for direct heating for buildings, swimming pools, or greenhouses. Power generation from geothermal wells requires that the fluids be close to or above boiling in order to power generators. "So far, only a handful of wells have been identified that have bottom hole temperatures of $120-130$ degrees Celsius, are three to 3.5 kilometers deep and near to a market and a transmission line tie-in station — the criteria needed for conventional geothermal power production." 33 Oil and gas wells of this depth are typically located along the foothills of Alberta and far from existing transmission infrastructure. ${ }^{34}$ The industry expects that if geothermal is to utilize existing wellbores that this energy would be used for heating as opposed to power generation and that the conversion of inactive wells could forestall the abandonment of wellbores. ${ }^{35}$

In British Columbia, the Geothermal Resources Act applies to water that is over 80 degrees Celsius and gives the Province ownership of this resource. ${ }^{36}$ To date, Alberta has no similar legislation with regard to geothermal development, but Alberta Energy may develop geothermal energy policy as part of their Climate Leadership Plan. ${ }^{37}$ Any new policy and associated regulations will need to address liability issues associated with the transfer of existing wellbores that may or may not be abandoned, and royalties. ${ }^{38}$

\section{Historic and Ongoing Subsurface Conflicts ASSOCIATED WITH WELLBORES}

\section{A. Gas Over Bitumen}

The existence of gas wells that penetrate the bitumen reservoirs put the production of the bitumen resources at risk because the gas wells were not constructed to withstand thermal recovery techniques commonly used in bitumen production.

In 1998, the Alberta Energy Utilities Board (EUB, now the AER) determined that producing gas associated with underlying bitumen was detrimental to the recovery of the bitumen and subsequently ordered that 146 gas wells be shut in. ${ }^{39}$ Since that time, several other shut-in orders have been made by the EUB or its successors. ${ }^{40}$ The Alberta government

Nick Wilson, "Alberta Government Eyes Geothermal Fix to Abandoned Well Crisis," Alberta Oil Magazine (5 October 2016), online: <energynow.ca/2016/10/alberta-government-eyes-geothermal-fixabandoned-well-crisis/ $>$.

Ibid.

Geovista, supra note 9 .

Wilson, supra note 32.

RSBC 1996, c 171, s 1(1).

Wilson, supra note 32 .

New Zealand may be a jurisdiction to look to for guidance as they have a well established royalty system associated with thermal energy: see Sam Malafeh \& Basil Sharp, "Role of Royalties in Sustainable Geothermal Energy Development” (2015) 85 Energy Policy 235.

Gulf Canada Resources Limited Request for the Shut-In of Associated Gas Surmont Area (15 February 2007), 2000-22, online: Alberta Energy and Utilities Board < aer.ca/documents/decisions/2000/200022.pdf $>$ (rescinding an order to produce documents).

40 Alberta Energy Regulator, "Products and Services Catalogue: Shut-In Order (SI Order)," online: $<$ www1.aer.ca/ProductCatalogue/335.html $>$. 
developed a compensation scheme for the gas producers through amendments to the royalty regulations. $^{41}$

A review of the AER data indicates that there are approximately 850 gas wells in the McMurray or Wabiskaw formations that are currently shut in or suspended and another 700 that are abandoned. ${ }^{42}$ In a strange twist, the only way that the gas producers can collect the royalty relief offered by the government for not producing is to ensure that the wells are not abandoned since a well must be capable of production to maintain the mineral lease. ${ }^{43}$ Thus, they sit in a suspended state.

These gas wells, abandoned or not, pose a potential limitation to thermal bitumen recovery operations. Now, regulations require wells that penetrate the bitumen reservoirs must be constructed and abandoned with thermal cement. It is estimated that only half of these gas wells are constructed with thermal cement. ${ }^{44}$ The lack of thermal cement may make wells prone to leak and failure when exposed to high temperatures.

The AER recognizes the potential negative impact of wellbores penetrating in situ thermal recovery reservoirs. In recent years, there have been releases of bitumen to surface or above the cap rock. Although there is some disagreement as to the cause of these releases, there are indications that wellbores penetrating the reservoir may be to blame. ${ }^{45}$ Draft Directive 23 indicates that a project proponent must take into account existing wells in the project area: "The [AER] expects that all wells penetrating the target formation or deposit in the project area be completed or abandoned in a manner that is compatible with proposed in situ

41 The following description of the royalty amendment was described by Perpetual Energy Inc, News Release, "Perpetual Energy Inc. Provides Additional Information on the Prior Period of Restatement of Gas Over Bitumen Royalty Adjustments" (14 April 2014), online: <www.newswire.ca/news-releases/ perpetual-energy-inc-provides-additional-information-on-the-prior-period-restatement-of-gas-overbitumen-royalty-adjustments-514082561.html>:

In 2004, an amendment to the Natural Gas Royalty Regulation (“Amended Regulation") was enacted by the Government of Alberta to help address the financial impact on the working interest owners of shut-in gas wells (the "GOB Program"). The Amended Regulation includes a mechanism for the Minister of Energy to provide temporary assistance to impacted owners based on prescribed quantities of foregone production from eligible shut-in wells. The temporary assistance is provided by way of monthly reductions in the gas crown royalty otherwise payable by the operators of these shut-in wells (the "GOB Royalty Adjustments").

The GOB Royalty Adjustments are based on a deemed production volume at the shut-in date, declining at $10 \%$ per year, and were to be provided for a period of up to 10 years from the shut-in date. The GOB Royalty Adjustments are paid to operators through a credit against their crown royalty invoice (not paid in cash).

The Amended Regulation also provides for the repayment by impacted owners of GOB Royalty Adjustments received should a well return to production (the "GOB Obligation"). The repayment of the GOB Obligation is structured as a gross overriding royalty ("GORR") of 1 percent for each year that the GOB Royalty Adjustments were received for a well, up to a maximum of $10 \%$ (the "Expected GORR") with a ceiling GOB Obligation equal to the GOB Royalty Adjustments received for the well. The measurement of the provision for the GOB Obligation, which represents the discounted amount of the Company's best estimate of expected repayments of the GOB Royalty Adjustments, will vary based on significant inputs in the Company's independent reserve report for the shut-in gas wells including the assumed dates of recommencement of production, estimated future production forecasts and natural gas price forecasts as well as discount rates. Geovista, supra note 9.

Petroleum and Natural Gas Tenure Regulation, Alta Reg 263/1997, s 17(2)(b) [PNGTR].

Geovista, supra note 9.

Alberta Energy Regulator, "Root Cause and Regulatory Response Report: Canadian Natural Resources Ltd. Primrose Bitumen Emulsion Releases, 2013" (Calgary: AER, 2016) at 42, online: <aer.ca/ documents/reports/IR 20160321-CNRL.pdf>; Energy Resources Conservation Board, "Total E\&P Canada Ltd. Surface Steam Release of May 18, 2006 Joslyn Creek SAGD Thermal Operation: ERCB Staff Review and Analysis" at 21, online: $<$ aer.ca/documents/reports/ERCB_StaffReport_JoslynSteam Release_2010-02.pdf $>$. 
operations; cement and casing must be designed to withstand anticipated operating temperatures and pressures to ensure reservoir fluid containment." ${ }^{, 46}$ Although this directive is a draft, the AER is requiring applicants take this risk into consideration since the in-force Directive 23 has not been updated since 1991, prior to the recognition of the potential impacts. $^{47}$

The fact that over 1500 gas wells, half of which were not constructed to withstand thermal operations, penetrate the bitumen zones creates a significant risk to the safe production of bitumen still in place and thus a risk that these reserves may not be producible.

\section{B. Potash Mining (Saskatchewan)}

The Saskatchewan government has long recognized the threat that wellbores pose to the development of their vast potash resources. Drilling for oil and gas is restricted in the potash mining areas of Saskatchewan. ${ }^{48}$ Saskatchewan, by restricting development, has demonstrated that the protection of the Prairie Evaporite (potash bearing zone) is paramount to oil and gas production in the area. ${ }^{49}$ While there is not a full prohibition on petroleum development, drilling a well in this area requires additional safeguards to reduce the risk of mine flooding or loss of well control due to contact with the Prairie Evaporite.

\section{UnCONVENTIONAL OIL AND GAS}

The AER refers to unconventional hydrocarbon resources as: tight oil or gas, which is found in low-permeability rock, including sandstone, siltstone, shale, and carbonates; shale gas, which is natural gas locked in fine-grained, organic rich rock; or coal bed methane, which is natural gas contained in coal. ${ }^{50}$ These resources often require the use of hydraulic fracturing in order to produce oil or gas.

The development of unconventional subsurface oil and gas resources faces a considerable risk from pre-existing wellbores. The construction of wellbores historically did not protect subsurface strata that had low permeability and porosity. The regulations stipulate which hydrocarbon bearing zones were to be protected by cementing but allowed overlying strata (typically shales and coals) to remain uncemented unless there was a potential shallower hydrocarbon bearing zone. ${ }^{51}$ In fact, the cementing requirements have not changed since 1990..$^{52}$ However, over time, the understanding of "hydrocarbon bearing zone" has changed with technologies that have allowed for unconventional resources to be produced.

$46 \quad$ Draft-D023, supra note 5, s 7.8.

Personal correspondence with AER staff.

OGCR, supra note 14, ss 26-27.

Nigel Bankes, "Disputes Between the Owners of Different Subsurface Resources" in Donald N Zillman et al, eds, The Law of Energy Underground: Understanding New Developments in Subsurface Production, Transmission, and Storage (Oxford: Oxford University Press, 2014) 433 at 447 [Bankes, "Disputes Between Owners"].

50 Energy Resources Conservation Board, "Regulating Unconventional Oil \& Gas in Alberta" (Calgary: ERCB, 2012) at 2, online: <aer.ca/documents/projects/URF/URF_DiscussionPaper_20121217.pdf $>$. D009, supra note 13 , s 5(c).

Ibid. 
The development of horizontal wells and the application of hydraulic fracturing in unconventional wells has created a situation whereby zones that had not been classified as hydrocarbon bearing are now actively being developed. ${ }^{53}$ Most of the discussion around hydraulic fracturing has been focused on the threat to the environment and, in particular, water. ${ }^{54}$ However, the extended reach and treatment of these wells in close proximity to historic vertical wells have created a conflict that could impact future resource development. ${ }^{55}$ In fact, there have been numerous "hits" on pre-existing wells from multistage fractured horizontal wells. Between 2009 and 2012, the Energy Resources Conservation Board (ERCB), now the AER, gathered information on unintended interwellbore communication due to hydraulic fracturing and recorded 20 reported incidences between 2009-2012. Some of these interactions were between wells over a kilometre apart and about half resulted in significant damage to surface equipment, producing wells, and the potential for public safety risk, groundwater contamination, or other environmental impacts. ${ }^{56}$

The implications of inter-wellbore communication, due to hydraulic fracturing, were recognized by the ERCB when it issued Directive 83 in 2013. ${ }^{57}$ This Directive requires operators to assess wellbores within the area of influence, including abandoned wells, to determine and mitigate any risk. ${ }^{58}$ To date, no inter-well hits have been the subject of litigation, but the risk has been recognized:

In the event that such impacts do occur, producers conducting [hydraulic multi-stage fracturing] operations can expect to be faced with claims from the affected producers for the value of any lost production, third party damages related to a failure to meet contracted production volumes, and to be indemnified with respect to any claims that may be advanced by a landowner whose property may have been damaged. ${ }^{59}$

Another possible implication of unconventional resources is the development of shallow resources, such as coal bed methane (CBM) and the potential impact on existing potable water resources. In Ernst v. Encana, Jessica Ernst alleged that Encana's development of CBM by drilling and hydraulic fracturing in proximity to her water well caused contamination of her water source ${ }^{60}$ The Court did not determine the issue of whether or not Ernst's well had been contaminated due to Encana's activities. It is interesting to note however that in Alberta, where any oil and gas development occurs above the base of groundwater, these wells are restricted from producing water; thus, CBM exploitation is not allowed in water bearing coals. ${ }^{61}$ In addition, fracturing above the base of groundwater is not

Lucas, Watson \& Kimmel, supra note 11 at 129.

SL Sakmar, "Shale Gas Developments in North America: An Overview of the Regulatory and Environmental Challenges Facing the Industry," (Paper delivered at the SPE North American Unconventional Gas Conference and Exhibition, Texas, 14-16 June 2011) [unpublished].

Lucas, Watson \& Kimmel, supra note 11 at 135.

Kim, supra note 2.

D083, supra note 4 .

Ibid, s 3.

Keith Luft, Thomas O'Leary \& Ian Laing, "Regulatory and Liability Issues in Horizontal Multi-Stage Fracturing" (2012) 50:2 Alta L Rev 403 at 432.

Ernst $v$ EnCana Corporation, 2013 ABQB 537 at para 1 [Ernst].

Alberta Energy Regulator, "Directive 044: Requirements for Surveillance, Sampling, and Analysis of Water Production in Hydrocarbon Wells Completed Above the Base of Groundwater Protection," online: <aer.ca/documents/directives/Directive044.pdf>. 
allowed in close proximity to water wells, and the fluids used in the operation is also restricted. ${ }^{62}$

Other issues regarding CBM have generally been resolved in terms of ownership with the Alberta government declaring that CBM is natural gas and always has been ${ }^{63}$ However the production of CBM through wellbores could potentially impact the development of the coal resource in the future, in particular if CBM wellbores penetrate coal resources that could be extracted as synthetic gas through coal gasification. ${ }^{64}$

\section{Natural Gas Storage}

Depleted gas reservoirs make excellent gas storage facilities. However, the existence of wells penetrating the reservoir creates a risk to the utilization of the pore space resource due to the possible escape of the stored gas. ${ }^{65}$ "[A] reas with too many abandoned wells particularly wells that have been improperly plugged and thus could serve as conduits for leaking gas — are not conducive to natural gas storage without careful remediation." ${ }^{\circ 6}$

There have been issues related to natural gas storage reservoirs and nearby wells in Alberta. In two separate well licence applications, CrossAlta Gas Storage \& Services Ltd. objected to Kallisto Energy Corp. drilling a well in close proximity to a gas storage reservoir. ${ }^{67}$ CrossAlta expressed concern that, although the new wells did not target the storage reservoir, the wells were in close proximity and could potentially drain storage gas. In one case, the well was not expected to penetrate the same geological zone as the storage reservoir. In both cases, the regulator granted permission to drill, acknowledging that to deny the applications would provide CrossAlta with a buffer zone that they had not acquired through a mineral lease. ${ }^{68}$ In another situation involving the same storage facility, CrossAlta brought an action against Bonavista Energy Trust alleging that a well, fractured in an overlying strata, had accessed the storage reservoir and hence produced stored gas. ${ }^{69}$

These conflicts highlight the industry's concern that wellbores penetrating a storage reservoir could result in the loss of stored gas. The pre-existence of wellbores will also limit the number of reservoirs suitable for gas storage in the future.

D083, supra note 4, ss 4-5. This directive supersedes Directive 27, which was released in 2006, after Jessica Ernst alleged in Ernst, supra note 60 at para 1, that her water was contaminated due to fracturing above the base of groundwater conducted between 2001-2006. MMA, supra note 16, s 10.1; Encana Corporation v Devon Canada Corporation, 2012 ABCA 271. See Astrid Kalkbrenner, "Underground Coal Gasification: A Regulatory Framework for Alberta" (2014) 51:3 Alta L Rev 525 at 525.

Brent Miyazaki, "Well Integrity: An Overlooked Source of Risk and Liability for Underground Natural Gas Storage. Lessons Learned from Incidents in the USA" in DJ Evans \& RA Chadwick, eds, Underground Gas Storage: Worldwide Experiences and Future Development in the UK and Europe (London: The Geological Society, Special Publications, 2009) 163 at 163.

Wiseman, supra note 1 at 1573.

Re Kallisto Energy Corp (23 July 2013), 2013 ABAER 013, online: <aer.ca/documents/decisions/ 2013/2013-ABAER-013.pdf> [Kallisto 2013] (application for a well licence Crossfield East Field); Re Kallisto Energy Corp (2012), 2012 ABAER 005 (application for a well licence Crossfield East Field). Kallisto 2013, ibid at para 29; Bankes, "Disputes Between Owners," supra note 49 at 446. Luft, O’Leary \& Laing, supra note 59 at 425. 


\section{E. Carbon Dioxide Sequestration}

The issues for carbon dioxide sequestration (commonly referred to as carbon capture and storage (CCS)) are similar to those of underground gas storage. The impact of wellbores on the integrity of CCS reservoirs has long been acknowledged..$^{70}$ During the hearing for the only CCS storage facility to be approved in Alberta, the Shell Quest Project, Shell acknowledged that the greatest risk to $\mathrm{CO}_{2}$ containment was the presence of four pre-existing abandoned wellbores which penetrated the storage reservoir. ${ }^{71}$ Understanding that further wellbore penetrations would compromise the containment of the reservoir, and that:

\footnotetext{
In its discussion with the ADOE [Alberta Department of Energy], Shell requested that petroleum and natural gas $(\mathrm{P} \& \mathrm{NG})$ rights that extend down to the ZOI [zone of interest] within the AOI [area of influence] not be re-posted or reissued when they expire and revert back to the Crown, given the potential risk to sequestration of the $\mathrm{CO}_{2}$. Further, Shell understands that there is notification in the ADOE system such that P\&NG rights in the ZOI within the AOI are no longer available. ${ }^{72}$
}

So here we see the impact of wellbores on the potential use of a reservoir for CCS as well as the implications for further resource development where CCS has been undertaken.

\section{F. STACKED RESERVOIRS}

In Alberta, both deep right reversion and, later, shallow rights reversion of minerals not exploited by the original licensee have created a situation whereby stacked reservoirs are being produced at the same time by different operators. ${ }^{73}$ Prior to the enactment of shallow rights reversion legislation, operators would normally drill to the deepest horizon of interest. After that horizon had been depleted or sometimes concurrently, the operator would move up hole and exploit shallower resources within the same wellbore.

The increase in mineral leases available has the effect of increasing the number of wellbores on the landscape. Since spacing requirements are based on a geologic zone or pool, now with the mineral rights severed into many leases, a drill spacing unit could have multiple wells in the same general geographic location. ${ }^{74}$

This increase in well density could ultimately impact the availability of the subsurface for further exploitation for other purposes such as gas storage, $\mathrm{CO}_{2}$ storage, or enhanced recovery. In the future, the density of abandoned wells could have a significant impact on groundwater resources since, regardless of the zone each well was targeting, they will all pass through the useable aquifers.

Mark Anthony de Figueiredo, The Liability of Carbon Dioxide Storage (PhD Thesis, Massachusetts Institute of Technology, 2007) [unpublished]; Watson \& Bachu, supra note 13.

Re Shell Canada Limited (10 July 2012), 2012 ABERCB 008, online: <aer.ca/documents/decisions/ 2012/2012-ABERCB-008.pdf> (application for the Quest Carbon Capture and Storage Project - Radway Field).

72 Ibid at para 122

73 Allan Ingelson \& Will Randall, "Shallow Rights Reversion: Uncertainty and Disputes"(2010) 48:2 Alta L Rev 397 at 401.

OGCR, supra note 14, s 4.021(1). 


\section{G. ENHANCED RECOVERY}

In the beginning of oil development, gas was a waste and there was little understanding of the drive mechanism that gas provided in the recovery of oil. Hence early producers flared off gas. Later understanding of reservoir mechanics led to conservation measures that did not allow the production of gas cap gas until oil had been recovered or other methods of pressure maintenance were in place. ${ }^{75}$ In Alberta, the first legislation was passed in 1932 with the Turner Valley Conservation Act. ${ }^{76}$ Even with gas conservation, existing oil and gas reservoirs have over 70 percent of original oil in place. As technology advances, higher recovery can be achieved..$^{77}$ One aspect of technology advancement is enhanced recovery, often referred to as enhanced oil recovery (EOR).

The first type of EOR was waterflooding. Water is injected to replace the gas and fluids that are recovered from a reservoir. The water maintains the reservoir pressure, thus reducing lifting cost. In addition, the water can act as a drive to push oil through the reservoir to producing wells. Early on, the risk associated with waterflooding on adjacent land was recognized, and the possibility of liability for damage caused by waterflooding discussed. ${ }^{78}$

Technologies like miscible flooding use oil chemistry and a miscible fluid (like solvents) to make trapped oil more mobile within the reservoir. $\mathrm{CO}_{2}$ flooding fits into this category by reducing oil viscosity and also providing a phase change behaviour that increases reservoir drive. In bitumen producing areas where deposits are too deep to mine, similar technology advances have been seen. Early technologies included huff and puff, steam flooding, fire flooding, and so on.

In the bitumen producing areas of Alberta, current technology development in horizontal well drilling and bit steering capabilities have created the potential for Steam Assisted Gravity Drainage and Toe to Heel Air injection. The industry has recently begun employing a combination of solvents and steam in order to increase recoveries and reduce GHG emissions and water use. Other technologies in the bitumen areas, where deposits are too deep to mine but too shallow to withstand the pressures required for thermal recovery, include imposing electric current to the connate water in the reservoir to heat the bitumen and mobilize it. While many of these technologies are experimental and their efficiency is yet to be determined, there is no doubt that their use will be accompanied by risks that were previously unrecognized for future resource exploitation, such as mining operations, (subsidence) water resource use, geothermal energy development, waste storage, and so on.

Almost all of these enhanced recovery methods involve increasing the reservoir pressure. Increased pressure combined with foreign fluids and temperature changes may create corrosive environments. These changes could have a significant impact on pre-existing wellbores, which were not designed to withstand higher pressures or the chemistries created

\footnotetext{
75 CE Reistle, Jr, "Reservoir Engineering" in DV Carter et al, eds, History of Petroleum Engineering (Washington, DC: American Petroleum Institute, 1961) 811.

SA 1932 , c 6 .

Aguilera et al, supra note 10 at 149.

EM Bredin, "Legal Liability for Water Flooding in Petroleum Reservoirs in Alberta" (1961) 1:6 Alta L Rev 516 at 528.
} 
within the reservoir. It is possible that, because of the multitude of legacy wells penetrating a reservoir, new technologies will be unsafe to deploy, thus sterilizing the resource.

\section{LEGISLATIVE AND REGULATORY BARRIERS}

Conflict and disputes in the subsurface are not new. These disputes historically have centred on ownership and compensation and were generally dealt with at the time the conflict occurred, often with governments having to make choices about which resource or which owner would get priority over another. ${ }^{79}$ However, the impact of wellbores in the subsurface will not discriminate based on resource or ownership. Since the wellbore is already there, there will not be an opportunity for owners to "take their turn" in producing their resource or even for a particular resource to be preferred over another based on some form of public interest. So the question to be asked is: does the current legislative and regulatory structure adequately protect subsurface resources from the impact of wellbores, and in particular, abandoned wellbores that have no economic value? Is the legislation too complex and prescriptive to allow for changes in subsurface use?

\section{A. ONgoing LiabiLity}

The current legislation places liability for abandoned oil and gas wells on the last licensee of record, in perpetuity. ${ }^{80}$ Some have argued that legislation requiring clean-up, after abandonment and reclamation have been conducted based on the requirements at the time of closure, of environmental contamination caused by activity long in the past is being retroactively applied. But the courts, the Alberta Environmental Appeal Board, and the ERCB have determined that this is not retroactive application of legislation since the contamination was ongoing. ${ }^{81}$

In the interesting case of Dalhousie Oil Co, Re 2010 ERCB 2010-019, ${ }^{82}$ Southern Alberta Oil Company (SAOC) drilled a well close to the town of Turner Valley in 1911. In 1926, Dalhousie Oil Company Limited (Dalhousie) acquired SAOC and the well was abandoned in the subsurface. The well was cut and capped, and the surface reclaimed in 1958. In 2006, Dalhousie sold its small interest in Turner Valley Unit No. 7 to Signalta. ${ }^{83}$ The well was within the geographical boundary of the unit but did not penetrate the unitized zone. Dalhousie argued that the abandoned well was part of the sale to Signalta. The Board found that the well was not a unit well and therefore not part of the sale. Dalhousie was found liable for the re-abandonment of the well.

Bankes, "Disputes Between Owners," supra note 49 at 433-50.

OGCA, supra note 6 , s 29.

Imperial Oil Limited v Alberta (Minister of Environment), 2003 ABQB 388 at para 50; see also Nigel Bankes, "A Century of Liability for an Abandoned Well," online (blog): <ablawg.ca/wp-content/ uploads/2010/06/blog_nb_dalhousie_june2010.pdf $>$ [Bankes, "Century of Liability"], commenting on Re Dalhousie Oil Company Limited (2010), ERCB Decision 2010-19, online: <aer.ca/documents/ decisions/2010/2010-019.pdf > (Section 40 Review of Abandonment Cost Order No. ACO 2008-1, Turner Valley Field) [Dalhousie].

Dalhousie, ibid.

It is interesting to note that Dalhousie had no wells licenced to them in the unit. What they sold was a small working interest; thus, no well licences were transferred in the sale and the ERCB would not have been notified of the sale. For further discussion, see Bankes, "Century of Liability," supra note 81. 
One argument that Dalhousie failed to put forward at the time of the ERCB review was that because the ERCB's regulation prohibits the transferring of well licences for wells with reclamation certificates, for reclamation exempt wells, or where there is an overlapping reclamation certificate, ${ }^{84}$ Dalhousie would not have been able to transfer the well licence even if they had not overlooked or even been aware of the well when making the sale to Signalta.

In this situation the well was found leaking. There is no indication that the leak was caused by some extraneous situation such as an increase in reservoir pressure near the well or other operations. It appears as though the abandonment just failed over time.

The Dalhousie case is a harbinger of the future for oil and gas companies. It is unreasonable to expect a company, which has no other oil and gas assets or expertise in the industry, to be liable for a well they thought they disposed of at least 50 years prior. It is unreasonable to expect a licensee to monitor a well that they no longer own, since the ownership of the wellbore would have vested in the Crown after the expiration of the mineral lease as set out in the $M M A .^{85}$ In fact it is remarkable that Dalhousie still existed after that amount of time. Had it not, the industry, through the Orphan Well Association, would have paid the bill. ${ }^{86}$

The problem with ongoing liability for abandoned wells when it comes to resource protection is this: abandoned wells are difficult to transfer. If the licensee is still a viable entity, they may have some incentive to transfer the well since they will transfer the liability along with it. But what is the incentive for a developer whose operations will include the abandoned well in the area of influence (AOI) to take on that liability from the last licensee without a regulatory requirement to do so?

A new development could impact an abandoned well, but the requirements to take into account abandoned wells in the AOI as set out in Directive 83 suggest a detection plan. ${ }^{87}$ Impacts on abandoned wells will most likely occur in the subsurface, and detection could take months or years. When a problem is detected with an abandoned well, the first call by the regulator will be to the licensee of the well who maintains ongoing liability. The licensee will have the burden of proving causation and damages as part of a negligence action to sue the developer in the area.

The idea behind continued liability is the "polluter pays principle." Indeed, the Orphan Well Fund was set up recognizing this principle, since it is funded mainly by the oil and gas industry through a levy administered by the AER.$^{88}$ However, as this article has illustrated, applying this principle in practice results in wells that are never abandoned, increased

D006, supra note 15 , s 6 .

MMA, supra note 16 , s 32(1).

OGCA, supra note 6 , s $70(1)$.

D083, supra note 4, s 3.3.3.

OGCA, supra note 6, ss 73-74. At times, the government has made cash infusions to the fund, the most recent in May 2017 when they provided a \$235M loan: see “Alberta Offers \$235M Loan to Clean Up Orphan Wells," CBC News (18 May 2017), online: <cbc.ca/news/canada/calgary/orphan-wells-notleyannouncement-plan-cleanup-alberta-province-1.4121235>. 
litigation risk, and disincentives to future resource development. Perhaps a better principle to follow is those who get the benefit pay. ${ }^{89}$

The principle of those who benefit pay seems to be at play in the treatment of long-term liability with respect to the sequestration of $\mathrm{CO}_{2}$. The Government of Alberta enacted legislation that transfers the liability of the carbon storage facility to the government after closure:

Assumption of liability

121(1) On the Minister issuing a closure certificate to a lessee in respect of an agreement under this Part, the Crown

(a) becomes the owner of the captured carbon dioxide injected pursuant to the agreement,

(b) assumes all obligations of the lessee

(i) as owner and licensee under the Oil and Gas Conservation Act of the wells and facilities covered by that agreement,

(ii) as the person responsible for the injected captured carbon dioxide under the Environmental Protection and Enhancement Act,

(iii) as the operator under Part 6 of the Environmental Protection and Enhancement Act in respect of the land within the location of the agreement used by the lessee in relation to the injection of captured carbon dioxide, and

(iv) under the Surface Rights Act,

and

(c) releases the lessee from any obligations under section 56(2)(a) with respect to the wells within the location of the agreement used by the lessee in relation to the injection of captured carbon dioxide.

(2) The Crown shall indemnify a lessee referred to in subsection (1) against liability for damages in an action in tort brought by another party if

(a) the liability is attributable to an act done or omitted to be done by the lessee in the lessee's exercise of rights under the agreement in relation to the injection of captured carbon dioxide, and

(b) any other conditions specified in the regulations are met. 
(3) If prior to the issuing of a closure certificate to a lessee of an agreement under this Part the lessee ceases to exist, the Crown may in accordance with the regulations assume ownership of the captured carbon dioxide injected pursuant to that agreement.

(4) On issuing a closure certificate to a lessee the Minister shall notify the Regulator and any other person as required by the regulations. 90

This legislation accepts that it is in the public interest to sequester carbon. The legislation creates a liability regime where the operator (who has some benefit) takes liability during the life of the project. Companies, like Shell Canada who owns and operates the only $\mathrm{CO}_{2}$ storage facility in the province, ${ }^{91}$ surely have some economic benefit from these projects, if only in the form of government grants. ${ }^{92}$ The operator transfers liability to the other beneficiaries, the public, after satisfying all regulatory requirements of operation and closure.

The development of oil and gas resources in the province, since 1930 when minerals were transferred from the Government of Canada to Alberta, ${ }^{93}$ have benefited the public in terms of royalties, economic development, and other taxes. Based on this substantial benefit, it seems fair that the public bear some responsibility for long-term liability. The cost of locating the licensee of wells that may have been abandoned decades ago and then going through the legal process in order to get them to pay, or recovering the cost from the Orphan Well Association, seems extreme.

\section{B. Wellbore ABANDONMENT AND CONSTRUCTION REGULATION}

Wells are constructed based on the requirements at the time a well is drilled and abandoned to the standard set by the regulations at the time of abandonment. Subsurface construction and abandonment requirements have become more stringent over time. ${ }^{94}$ Recognition of the importance of protecting non-saline water has spurred on most of the changes in abandonment and construction requirements. ${ }^{95}$

In addition, the AER has implemented stricter abandonment requirements that try to anticipate future reservoir conditions, such as requiring the operator to use thermal quality

MMA, supra note 16, s 121, as amended by Carbon Capture and Storage Statutes Amendment Act, 2010, SA 2010, c 14, s 2(18).

There are other $\mathrm{CO}_{2}$ injection sites in the province but they are for the purposes of enhancing recovery or used in conjunction with the disposal of $\mathrm{H}_{2} \mathrm{~S}$.

The Government of Alberta has committed \$1.24B to two projects, one of which is the Shell Quest project. See Government of Alberta, "Carbon Capture and Storage," online: <alberta.ca/carbon-captureand-storage.aspx $>$.

Natural Resources Transfer Agreement, Schedule II of the Constitution Act, 1930 (UK), 20 \& 21 Geo $\mathrm{V}, \mathrm{c} 26$.

Directive 20 and its predecessor regulations have been amended at least eight times since abandonment requirements were put into the OGCA in 1969.

The first requirements for groundwater protection at the time of abandonment appear in the EUB Guide 20 in 1994. In 1990, the cementing requirements as set out in the cementing Guide 9 based on the OGCR called for protection of useable water; at that time, there was no definition regarding what useable water meant, but most operators interpreted this as groundwater that was in use based on water wells in the area. In 1996, Alberta Environment established a definition of non-saline water as water with TDS of less than $4000 \mathrm{mg} / \mathrm{l}$; this is the standard that has been used since to interpret Directive 9, which has not been changed since 1990 . 
cement when abandoning any well that penetrates a bitumen zone, which ultimately increases the cost of abandonment to the current licensee while benefiting some future development. ${ }^{96}$ Some industry participants have suggested that the increased cost of abandonment deters companies from abandoning their wells. ${ }^{97}$ Further evidence suggests that the cost of abandonment is directly related to a company's decision to abandon a well. A study conducted by Lucija Muehlenbachs found that "[t]he most effective way to reduce the number of inactive wells ... is by reducing the cost of their abandonment." 98 Recently there have been concerns over the timeliness of abandonment and the potential unfunded liability that may exist due to oil and gas companies becoming insolvent. ${ }^{99}$

The logical question that follows is whether the increased cost of anticipating the subsurface conditions at sometime in the distant future is worth the delay in abandonment and the potential for significant unfunded liability due to inactive wells on the landscape. Would it be better to mitigate the risk of wellbores when the risk is imminent and quantifiable? Would the economics prove better if the cost of mitigating these risks were pushed out to the future, instead of burdening an already stressed oil and gas economy? "A reading of the literature reveals two common bases upon which scholars typically suggest limits to environmental liability; notions of fairness and efficiency." ${ }^{100}$ I submit that it is not fair or efficient to burden a company like Dalhousie, who presumably followed the rules, with the liability of re-abandonment of a well that is nearly 100 years old. Further, burdening companies with this liability creates a disincentive to investment.

Looking to the future and the new uses and stresses that the subsurface will be subjected to, it would be more efficient and fairer to follow the example of $\mathrm{CO}_{2}$ storage and transfer long-term liability of wellbores to the Province. Developers then would have the surety that they would have access to these wellbores when the risks required re-entry. In addition, the public, surface owners, and financial institutions would be able to take comfort in knowing that the government would be responsible for the wells, instead of a corporation that may have exited the market or dissolved. Further, the government would be able to factor the risks associated with wellbores into the approvals for new development, which would be an improvement over the current situation that reacts when an impact occurs.

\section{Well LiCEnCING REQUiRements For AbANdONEd WellS}

AER Directive 56 describes the requirements for obtaining the rights to an abandoned wellbore.

$96 \quad$ D020, supra note 12, s 5.4.

Ryan Munro, "Timeliness of Thermal Compatibility for Abandoned Wells" (Address delivered to Canadian Society of Gas Migration, Calgary, 15 September 2016) [unpublished].

98 Lucija Muehlenbachs, "80,000 Inactive Oil Wells: A Blessing or a Curse?" (2017) 10:3 U Calgary School Public Policy 1 [Muehlenbachs, "80,000 Inactive Oil Wells"]; see also Lucija Muehlenbachs, "A Dynamic Model of Cleanup: Estimating Sunk Costs in Oil and Gas Production" (2015) 56:1 Intl Economic Rev 155.

99 Redwater Energy Corporation (Re), 2016 ABQB 278, aff'd Orphan Well Association v Grant Thornton Limited, 2017 ABCA 124, rev'd Orphan Well Association v Grant Thornton Ltd, 2019 SCC 5; Michelle Bellefontaine, "\$260B Liability Figure for Abandoned Energy Infrastructure an 'Error in Judgment': AER," CBC News (1 November 2018), online: <cbc.ca/news/canada/edmonton/alberta-energy-regulatorliability-figure-error-1.4888532>. 
Wellbore rights are separate and distinct from mineral rights and require separate approval before a well licence application can be filed.

32) Before filing a well licence application with Facilities Applications, the applicant must acquire the rights to the abandoned wellbore:

a) For Freehold mineral rights, the applicant must obtain the abandoned wellbore rights from the licensee of record. If the applicant is unable to acquire an agreement from the licensee of record, the applicant must identify that in its application.

b) For Crown mineral rights, if the mineral rights have not expired, the applicant must obtain the abandoned wellbore rights from the licensee of record; if the mineral rights have expired, the abandoned wellbore rights revert to the Crown. In this case, the applicant must obtain well re-entry approval from the Crown using the Request for Well Re-Entry Approval form available on the Alberta Energy website. ${ }^{101}$

This provision illustrates the challenge faced by future developers who need to access an abandoned well to mitigate against the risks that the new operations could pose for the existing wellbore. Since the licence must be obtained from the licensee if the minerals have not expired for Crown leases or any freehold lease, there could be conflict arising with an existing licensee demanding payment for an otherwise worthless wellbore and essentially holding the new developer hostage. This situation is analogous to the common carrier problem where the owner of a pipeline restricts access to transportation volumes to competitors' oil or gas. While it is unclear whether this situation would result in legal action for access or applications to the regulator to force transfer, the risk is clearly present. The situation becomes even more complex if the minerals have not expired but the well has obtained a reclamation certificate, since Directive 006 prohibits the licence transfer for reclaimed wells. ${ }^{102}$

\title{
Directive 56 anticipates wellbore re-entry for remediation:
}

\begin{abstract}
Approvals for abandoned well remediation do not require a Directive 056 application. Companies responsible for the re-entry, repair, and reabandonment of a well must submit a nonroutine abandonment request to the AER, indicating the reason for the re-entry, a plan for resolution of the issue, and a statement about whether the company is the current licensee of the well, holds the mineral rights, and has a current surface lease agreement. If the request is approved, the AER will issue a letter of approval. If the company is not the current licensee, a Directive 056 application may be required.
\end{abstract}

Before submitting an application, authorization for re-entry, repair, and reabandonment must be obtained from the Alberta [Department of] Energy if applicable. ${ }^{103}$

It is not clear whether mitigation measures would fall into the classification of remediation. One would expect that it would be reasonable that this section would apply for 
that purpose. However, as the section currently reads, if the applicant is not the current licensee, further application will be required.

The simpler regulatory solution would be to have the licence revert to the Crown for further disposition, regardless of the use. Obviously a new applicant wishing to take over the licence would not have access to minerals leased by another, so there are no policy reasons why it should not be easier for a new applicant to acquire the wellbore. This solution would also ensure a licence renewal with a viable licensee.

\section{Mineral Lease}

As Directive 56 states, "[w] ellbore rights are separate and distinct from mineral rights."104 Therefore, the licencing and re-entry of wells should not be so closely associated with the minerals that a well potentially accesses:

Before submitting a well licence application, the applicant must

a) be a working interest participant;

b) be entitled to the right to produce the oil, gas, or crude bitumen from the well or have the right to drill or operate the well for the authorized purpose;

c) acquire the right to produce from the intended formation for the complete [drilling spacing unit (DSU)]. Part 4 of the OGCR states requirements for normal DSUs and for special DSUs. Applicants need to be aware that fractional sections require a special DSU if the size of the fractional section differs by more than 5 per cent from a normal DSU. The applicant must ensure that it acquires the rights for the entire DSU for the intended purpose of the well prior to submitting the application. ${ }^{105}$

The requirement to have a well that is "productive" or "potentially productive"106 to ensure that a mineral lease continues impacts the decisions of whether or not to abandon a well. If minerals could be retained on some other basis, then inactive wells may be abandoned in a timelier manner. In terms of subsurface use, this could potentially limit the objectives of rights reversion and thereby limit the proliferation of wellbores that will eventually impact future development. Under the current liability management system, the mineral lease has no effect because they are not considered assets. The sale of the lease may not be captured to ensure that the well licence is properly connected to the lease owner, thus creating a situation where abandonment orders may be issued and a useful well abandoned and replaced with another, again increasing well proliferation. 


\section{E. SURFACE IMPACTS}

Subsurface resources cannot be exploited without access from the surface. The proliferation of wellbores has a significant impact on surface use. In fact, the existence of an abandoned well restricts the surface development in Alberta:

[T] he AER has established minimum setback requirements in this directive to address public safety issues that could result from an abandoned well. While the likelihood is low that future access to an abandoned well for repairs will be needed, establishing and maintaining a greater setback than is required should be considered between the abandoned well and surface structures to

- allow well access with minimal disruption to surface structures and

- $\quad$ prevent accidental contact of the construction equipment with the well.

Applicants are strongly encouraged to address the need for a greater setback with the licensee before submitting their application to the municipality.

The SDR requires the municipality to ensure that applicants seeking subdivision or development approval have appropriately identified and considered locations of abandoned wells, including any prescribed setback area, when making planning, development, and construction decisions. The municipality may require a larger setback than the minimum requirement set out in this directive.

Surface structures on top of an abandoned well are not permitted and a minimum $5 \mathrm{~m}$ setback radius around the well must be maintained. ${ }^{107}$

Further, "drilling an oil or gas well can prevent future surface use - for example, many municipalities in Texas prohibit building on top of or within a certain number of feet of an abandoned well. Yet current and potential future surface and subsurface users often have no voice, or a very limited voice, in the decision to drill." ${ }^{\prime 108}$ The situation is no different in Alberta; surface owners, while compensated for well leases prior to abandonment and reclamation are not compensated for the abandoned well left beneath their property or the restriction on development. The easy reuse and re-entry would create a situation whereby surface leases would be continually renegotiated for access, reduce the ultimate number of wellbores, and ensure that surface risks associated with wellbores are adequately mitigated when new subsurface uses are contemplated. 


\section{Conclusion}

Returning to the questions posed at the outset of this article:

Should the licensee of a wellbore, having been abandoned decades prior to a new development, be required to abandon a well to withstand some future technology that was not contemplated at the time of abandonment?

The current regulations for construction and abandonment do in fact attempt to envision some aspects of what may happen in the subsurface in close proximity to a well. The economic cost associated with a well abandonment or increased construction requirements may not be justified when considering the time value of money and whether the increased requirement will actually protect the wellbore and the future use of the proximal subsurface. As the Dalhousie case demonstrates, even if the requirements of the day are followed, wellbore failure is possible and even probable over time. It makes more financial sense to burden a new development with the costs of mitigating the risks of that development. Economic decisions can be made at the time the risk is to be imposed in a more reasoned manner than trying to imagine what might be required 100 years in the future.

The impact of increasing the cost of abandonment to protect some future use of the subsurface has the perverse outcome of discouraging the abandonment of wells and leaving unsecured liability of inactive wells on the landscape. ${ }^{109}$

Should the licensee be required to re-enter and re-abandon a wellbore to allow for safe exploitation in the future, or should the company that will be conducting the new operations be expected to pay?

The answer to this question requires a consideration of fairness and efficiency. A company constructing and abandoning a well decades before a new technology is introduced cannot possibly be expected to imagine the increased stress induced into the reservoir that the well penetrates. Companies that follow the regulations should be able to reasonably expect that compliance with the rules will alleviate liabilities in the future. The Crown's duty to regulate should mean that the regulated industry is able to trust the expertise of a regulator to ensure the protection of the environment, public safety, and the subsurface resource. After all:

The mandate of the Regulator is

(a) to provide for the efficient, safe, orderly and environmentally responsible development of energy resources in Alberta through the Regulator's regulatory activities, and

(b) in respect of energy resource activities, to regulate

(i) the disposition and management of public lands, 
(ii) the protection of the environment, and

(iii) the conservation and management of water, including the wise allocation and use of water,

in accordance with energy resource enactments and, pursuant to this Act and the regulations, in accordance with specified enactments. ${ }^{110}$

What is the role of the Crown to ensure that resources continue to be exploited, for the financial benefit of its citizens, in a way that ensures environmental protection and public safety?

In Alberta, the subsurface is predominately owned by the Crown and by extension the people. The problem of wells in the subsurface is not just a "Tragedy of the Commons," 111 which is a problem of ownership, overuse, and access to the resource. This is not "simply (or not so simply) resource systems that "need to accommodate multiple uses that are most efficiently pursued at different scales, whether simultaneously or over time." "112 The wellbore creates an issue for all uses and users, regardless of their scale and time frame. The management of this liability will be crucial to the exploitation of subsurface resources of all types long into the future. A green future may mean the reduction in oil and gas resource exploitation but at the same time will mean the increased use of the subsurface pore space for pollutant disposal, extraction of other resources like potash to increase food production or uranium for alternative energy production, or geothermal applications.

The Crown needs to address the management of liability to ensure that not only current liabilities associated with inactive wells are adequately addressed, but that the future liability associated with abandoned wells is fairly and efficiently managed. Only by creating a fair and equitable system will we be able to incentivize the most efficient and beneficial use of the subsurface resources. 
[this page is intentionally blank] 